\title{
A COMPARATIVE STUDY ON DIFFERENT STATISTICAL MODELS FOR CALCULATING THE OPTIMAL HEDGE RATIO IN THE LIVE CATTLE MARKET
}

\author{
Um Estudo Comparativo de Diferentes Modelos Estatísticos para cálculo \\ da Razão Ótima de Hedge no Mercado de Boi Gordo
}

\begin{abstract}
Brazilian agribusiness has stood out in recent years for its efficiency and productivity growth, based on technology, planning, management of results, and continuous improvement of performance. In the live cattle market, the price oscillations show themselves as a risk that the producer has to minimize in order to ensure the success of his business. In this scenario, the futures market has been translated into an important hedging instrument, however, a confronting challenge is the identification of the production ratio that must be protected. Thus, this article aims to statistically compare the performance of six models for the calculation of the optimal hedge ratio in the Brazilian live cattle futures market: Ordinary least squares, BEKK, DCC by Tse and Tsui (2002), DCC by Engle and Sheppard (2001), time-varying beta correlations, and unconditional beta. The ratios were estimated for the log-returns of the daily and monthly price series of spot and futures live cattle, comprising the period from 10/2/2000 to 19/8/2014. It was noted that for the daily series, the contractual changes generate intertemporal breaks, resulting in the increased variance of the futures logreturns and the low optimal hedge ratio. For monthly series, it is concluded that the BEKK, followed by the unconditional beta are the best models when it comes to reduction of variance and maximization of the Sharpe ratio.
\end{abstract}

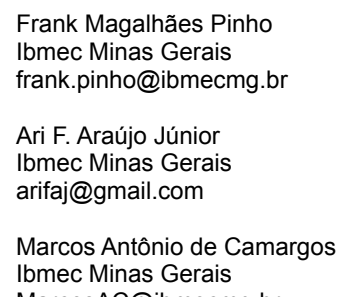

Recebido em: 08/03/2016. Aprovado em: 25/08/2017.

Avaliado pelo sistema double blind review

Avaliador científico: André Luiz Ribeiro Lima

DOI: $10.21714 / 2238-68902017 v 19 n 3 p 160$

\section{RESUMO}

O agronegócio brasileiro tem se destacado nos últimos anos por sua eficiência e pelo crescimento da produtividade, fundamentados em tecnologia, planejamento, gestão dos resultados e melhoria contínua de desempenho. No mercado do boi gordo, as oscilações apresentadas nos preços se apresentam como um risco que o produtor tem que minimizar para garantir o sucesso do seu negócio. Nesse cenário o mercado futuro tem se traduzido em um importante instrumento de hedge, mas um desafio com que se defronta é a identificação da proporção da produção que deve ser protegida. Assim, este artigo tem como objetivo comparar estatisticamente a performance (eficiência) de seis modelos para o cálculo da razão ótima de hedge no mercado Futuro de Boi Gordo brasileiro: Mínimos Quadrados Ordinários, BEKK, DCC de Tse e Tsui (2002), DCC de Engle e Sheppard (2001), Beta de Correlações Variantes no Tempo e o Beta Incondicional. As razões foram estimadas para os log-retornos das séries de preços diárias e mensais de boi gordo spot e futuro, compreendendo o período de 02/10/2000 a 19/08/2014. Constatou-se que para as séries diárias, as mudanças contratuais geram quebras intertemporais, fazendo com que a variância dos log-retornos futuros aumente e a razão ótima de hedge seja baixa. Para séries mensais, conclui-se que o BEKK, seguido do Beta Incondicional são os melhores modelos quando se trata de redução de variância e maximização do Índice de Sharpe.

Palavras-chave: Hedge, Razão Ótima de Hedge, Boi Gordo, Mercado Futuro, BEKK, DCC, Beta.

Keywords: Hedge, Optimal Hedge Ratio, Live Cattle, Futures Market, BEKK, DCC, Beta. 


\section{INTRODUCTION}

In recent years, Brazilian agribusiness has performed well above other sectors of the economy due to efficiency and productivity growth. It should be noted that this was only possible due to investments in research and technology, planning, management of results and performance improvement (DA COSTA, GUILHOTO and IMORI 2013).

Based on the perspective that economic activity is speculative in nature, as well as in almost all segments of agribusiness (commodities), price fluctuations, from the beginning to the end of production, represent one of the risks for that activities. A situation typical of the live cattle market, where the guarantee of a certain price that covers production costs and guarantees profit is a challenge that can be faced with the use of hedging instruments available in the financial market, such as futures contract. In this scenario, BM\&FBovespa's futures market plays an important role for the agents involved with commodities and for the economy.

Futures contracts can be understood as standardized contracts for buy and sell a particular commodity, in which all characteristics (quantity, quality, term, form and place of delivery, price and position fluctuation limits, etc.) are fixed a priori and whose negotiation does not necessarily imply the physical delivery of the traded commodity. They basically represent commitments to buy and sell a particular commodity in the future, whose settlement may be financial (\$) or through physical delivery of the traded commodity.

Futures contracts therefore provide opportunities for profit or at least margins that may result in the coverage of production costs, reducing the risk of price in the physical market, which in most economic activities involves a large number of speculative elements, making market behavior unknown (HARDAKER et al., 2004). Among the benefits of using futures contract, Montezano (1987) emphasizes the protection against price risk, reduction of transaction costs, increased competitiveness in the physical market (due to greater price visibility), the possibility of financing operations, and the efficient allocation of resources.

The live cattle market plays an important role within Brazilian agribusiness. Brazil has the world's largest commercial herd with more than 200 million head of cattle and the second largest cattle herd worldwide (behind only India), according to the United States Department of Agriculture (USDA) (2014). According to the Ministry of Agriculture, Brazil has been the leader in the world's largest beef exporter since 2004, with approximately $20 \%$ of all meat traded on the international market and sales to more than 180 countries. Furthermore, statistics point to a growing market due to the favorable climate and the potential for increasing agricultural areas in the country. Such factors, combined with a wide use of technology, have resulted in improvements in fertility and productivity, explaining the economic potential of the sector (IBGE, 2008).

Regarding the Futures live cattle market, Rochelle (1997) points out that because it is a non-stock commodity, the theoretical framework is still underdeveloped, since live animals do not have the same stability for the spot and futures prices, including some reasons for this assertion, such as constant production and distribution, non-existence of a fixed supply, and the possibility of storage. In this direction, Amorim Filho (2015) adds that, as well as in other agricultural markets, livestock agents are prone to high price volatility due to two factors: the time gap between the buy of feeder cattle and sell of live cattle, price forecast difficult or even impractical, which impute an inherent risk to the activity.

These factors increase the variability of prices (volatility), determined by the impossibility of fixing the supply, creating an even greater need of anticipation or price insurance for future date, since this mechanism is driven essentially by information available in the physical market (spot), which makes that the information increases the price instability of non-storable commodities (OLIVEIRA NETO and FIGUEIREDO 2008).

Due to these characteristics, studies aimed at quantifying the risk relationships inherent to the live cattle market are relevant in order to identify strategies to manage this risk, since the efficiency in its management is opposite to the implementation of efficient strategies due to their impacts and their non-static nature.

If on one hand futures contracts are widely used as a hedging strategy, on the other, it must be considered that, for this strategy to be efficient, it is necessary to estimate the appropriate production ratio that each trader should destine to futures contracts, i.e., the optimal hedge ratio.

In this context, the guiding question for this research is: what tools can be used in order to obtain efficient market risk management strategies? To answer this question, we aim to statistically compare the performance of six models for the calculation of the optimal hedge ratio in the Brazilian live cattle futures market: Ordinary least squares, BEKK, DCC by Tse and Tsui (2002), DCC by Engle and Sheppard (2001), time-varying beta correlations, and unconditional beta. In general terms, based on recent data from the Brazilian live cattle market, the contribution of this article is 
to identify models that may be considered more statistically adequate for the calculation of the optimal hedge ratio, thus providing a risk management strategy for this market.

Following this introductory section, section two presents the literature review on the evolution of hedging theory. In the third one, the methodology is presented, in which the models for the determination of hedge ratio are described. The fourth section presents the results of each model for daily and monthly data and a comparative analysis on the efficiency of each one. Finally, the conclusion is presented, followed by the consulted references.

\section{LITERATURE REVIEW}

\subsection{Risk and Price Risk}

It can be said that the study and risk management were strongly driven by the seminal study of Markowitz (1952), which pointed out that the selection of portfolios should be made based on the return maximization and risk minimization, represented by the variance of returns, being used until present days as one of the main measures of risk.

The term risk is a multidimensional construct, but involves the idea of getting undesired or under-expected results in almost all its nuances. According to Jorion (2007), it would be the volatility of unexpected results. From a more economic perspective, although in the same direction, Morgan (1996) associates risk with the uncertainty level of future returns and describes market risk as uncertainties arising from changes in observable conditions, such as shocks of supply and demand, exchange rate and production costs.

According to Duarte Júnior (1996), risk management involves three basic concepts: return, uncertainty, and risk. There are uncertainties associated with the return that will be obtained and, when it is possible to measure this uncertainty numerically, it is called risk. Therefore, risk can be characterized as how much an event is uncertain, being the variation positive or negative around the expected return.

As noted, volatility is a term commonly used in finance to refer to the variation of an asset's returns. It can be calculated in a number of ways, and variance is one of the main used forms since the study of Markowitz (1952).

Regarding the price risk, Hull (2011) highlights that exchanges occur in a single instant in the spot market at a price adjusted by supply and demand at the moment, usually with immediate payment and delivery of the commodity. In this scenario, the supply seasonality would be on the risk of price fluctuations (price risk).
According to Pindyck and Rubinfeld (2006), in the context of commercialization, the producer would be the weakest link in the industrial chain, having upstream (the input industry) and downstream (the food processing industry), both with oligopolistic and oligopsonic characteristics, respectively, with power over the price formation, with restrictions only by the limits imposed by the competitors themselves.

Regarding the agricultural market, as well as occurs in others, the sector agents are prone to high price volatility due to two factors: the time gap between the buy of feeder cattle and the sell of live cattle, difficult price forecasts or even impracticable, which impute an inherent risk to the activity (AMORIM FILHO, 2015). In this context, the formation process, and hence the price risk, is a risk to be analyzed in an efficient negotiation strategy, where the producer must seek tools to assist in their minimization or mitigation.

As pointed out by Bhaduri and Durai (2008), the effective use of futures contracts in hedging strategies has become the focus of the debates to find the optimal hedge ratio in the empirical literature on the theme due to the advances in the trading volumes performed in the futures markets in the last, signaling the increased concern for the traders on the management of risks involved in the agricultural activity.

\subsection{Hedge and Optimal Hedge Ratio}

Hedging strategy or simply hedge implies to maintain positions in both spot and futures markets in order to obtain protection against possible losses arising from adverse fluctuations in the commodity prices (GOMES, 1987). It is a key instrument for traders who do not wish to be exposed to future price changes in the futures of a particular market. In the context of the live cattle market, the farmer can hedge his selling price in the futures if he imagines that the live cattle price will drop. Likewise, the refrigerator can hedge against its purchase price in the futures if it imagines that the price will drop.

It can be said that the foundations of the theoretical framework on hedge were introduced by Keynes (1930) and Hicks (1939), for which hedging meant reducing risk exposure of some economic activity. In the theoretical evolution of the theme, Working (1953) added the idea of using hedge to maximize the profit of commodity producers and processors. However, one of the main theoretical contributions with practical application was given currently by Stein (1961) and Johnson (1960), who used Markowitz's portfolio theory (1952) to maximize the hedger's expected utility, considering a portfolio composed by positions both in spot and in futures market. Specifically, Stein (1961)

Organizações Rurais \& Agroindustriais, Lavras, v. 19, n. 3, p. 160-176, 2017 
developed a simple geometric technique, in which it is possible to simultaneously determine the spot and futures prices in the commodity market. With this analysis, it is possible to identify if variations in the spot and futures prices are determined by excess supply in the production chain or changes in price expectations.

In the aftermath, Ederington (1979) elaborated the first derivation of the optimal hedge ratio given by the covariance ratio of the spot and futures log-returns by the futures return variance, concluding that even those indifferent to the risk should hedge only a portion of the portfolio.

According to Guimarães (2005), expecting that future prices follow the martingale process (stochastic process without drift ), the optimal hedge ratio is those that minimizes risk, being called optimal because it is determined from the imposition that the portfolio (formed by the spot and futures positions) variance is minimal (HULL, 2011). In operational terms, it can be obtained by the ratio resulting from the division of covariance between spot and futures prices by the variance of futures prices (MYERS and THOMPSON, 1989).

When determining the hedge ratio (magnitude or size of the futures market position compared to the spot position), the differences (absolute or relative) in price changes in the spot and futures markets act as complicating factors in the setting up of hedging strategies, making it difficult to determine this magnitude. Thereby, the major issue for the hedger is to determine a ratio of how much to buy or sell in the futures market for each unit, called the optimal hedge ratio.

Analyzing prices from live cattle futures contracts, Myers and Thompson (1989) showed that it is theoretically and empirically inappropriate to use the slope of line from simple regression coefficient of the spot price on futures prices to estimate the optimal hedge ratio, since it is time-constrained, whereas the simple linear regression coefficient is not.

Myers (1991) analyzed models to estimate the optimal hedge ratio for the wheat futures market and found that the GARCH model shows hedge with better efficiency, but with improvement was marginal in relation to traditional models.

Gray (1995) developed a model to estimate the optimal hedge ratio through a univariate modeling of volatility from which several studies attempted to determine it from the multivariate model of volatility.

The study of Bera, Garcia and Roh (1998) showed that the MQO estimators are not the most appropriate for determining the optimal hedge ratio, since they infer that this ratio is constant over time and alternatively tested bivariate GARCH models to be able to deal with the heteroskedasticity problem of residues.

Lee and Yoder (2005) conducted an extension to the study of Gray's (1995) general regime-switching univariate, applying a bivariate Markov-switching regime (BEKK-GARCH model) for the maize and nickel markets in the United States. They concluded that BEKK model with regime switching is more efficient for hedging strategies in relation to BEKK without regime switching.

Alizadeh and Nomikos (2004) also used the Markov-switching regime approach to calculate the optimal hedge ratio to determine the hedge ratio of minimum time variance. They tested the hedging effectiveness of oil futures contracts using univariate and bivariate regime switching models with generalized autoregressive conditional heteroskedasticity (GARCH) error structure. They concluded that regime switching in GARCH models reduces volatility and increases prediction efficiency. The hedging ratios of Markov-switching regime models are superior to others in relation to portfolio risk reduction in the oil market, and the two-regime model better describes the dynamic relationship between spot and futures prices.

In general, researchers, such as Ederington (1979), Rolfo (1980), Anderson and Danthine (1981), Brown (1985), Myers and Thompson (1989) among others followed the idea of deriving the optimal hedge ratio from concept of profit maximization, in the sense that doing so within the average-variance space is perfectly plausible, given the concurrence of the decision for spot and forward positions.

\subsection{Review of the National Empirical Literature on Optimal Hedge Ratio}

Chiodi et al. (2005) compare the effectiveness of the Brazilian soybean market in Cascavel (PR) and Sorriso (MT) in the BM\&FBOVESPA Securities, Commodities and Futures Exchange (BM\&F) and the Chicago Board of Trade (CBOT), estimating the equation of daily price variations in the spot market as a function of the daily variations in prices on the futures market using ordinary least squares (OLS). They found that BM\&F's futures contract is more efficient than CBOT's in some months of the year in Cascavel for hedging, but in Sorriso, CBOT's futures contract is more efficient for hedging during the studied period.

Guimarães (2005) investigated whether the observations made by Myers and Thompson (1989) were valid for the Brazilian live cattle market and the effect on the estimation of daily and weekly series on the optimal hedge ratio. It was found that the use of weekly series is more appropriate for determination of the optimal hedge ratio, 
since it reduces the serial autocorrelation, and that regressions with price changes result in estimates of hedge ratio close to those obtained with the general model and that these reasons decrease with the increase of the hedge horizon.

Bitencourt, Silva and Sáfadi (2006) used two methods for calculating the optimal hedge ratio in the Brazilian live cattle market: 1 . the conventional (simple linear regression), assuming that the covariance matrix is constant; 2. The VaR model for the average and GARCH BEKK for the variance, which considers the temporal dependence of the matrix. The results indicate that the optimal hedge ratio is not constant over time, suggesting that the use of models that consider the temporal dependence of the series is more realistic.

Oliveira Neto and Figueiredo (2008) analyzed the live cattle hedging transactions in the futures market of the BM\&F Goiás and found that the Myers and Thompson (1989) model was the most efficient, with a risk decrease of approximately $90 \%$.

Zilli et al. (2008) estimated the optimal hedge ratio using the error correction mechanism (ECM) for daily, weekly, and monthly data and found that the optimal hedge ratio is very sensitive to the data frequency and that it presents better indexes when ECM is inserted into the estimation process, confirming that non-stationary series can provide erroneous estimates for the optimal hedge ratio when the cointegration relationships among the variables are not considered.

Cruz and Lima (2009) calculated the optimal hedge ratio using the error correction model of Engle and Granger (1987) and the general model of Myers and Thompson (1989) for the live cattle market in the state of São Paulo. The results showed that there is cointegration between the spot and the futures price series and there is bidirectional causality between them. For the daily series, the hedger should trade about $30 \%$ in the futures market in relation to its spot position and $55 \%$ of its spot position for weekly series. The variance of hedger income may be reduced by $52 \%$ and $78 \%$ for the use of daily and weekly series, respectively.

Aiming to identify the best method for calculating the optimal hedge ratio for the Brazilian live cattle market, as well as the differential of hedge ratios between the harvest and the off-season, besides finding out the reason why the estimates of optimal hedge ratios in the national literature are smaller than those in the international literature, Lazzarini (2010) concluded that the DCC models are the best of all when the objective is to reduce variance and increase the Sharpe ratio. The hedge ratio in the off-season should not be higher than in the harvest season. Moreover, the break in intertemporal expectation with change of contracts increases the variance on the futures log-returns series, decreasing the hedge ratio.

Rodrigues and Alves (2010) analyzed the research evolution on effectiveness and optimal hedge ratio and found evolutionary patterns in methodological procedures, despite the lack of methodological consensus in the estimates.

Souza, Cunha and Wander (2012) estimated the optimal hedge ratio and its effectiveness for the live cattle market in Goiás and found that the best adjustment model (in the first difference with obsolete terms in the BM\&F's futures market price series) showed the optimal hedge ratio of $69 \%$ and its effectiveness value of $80 \%$.

Amorim Neto (2015) evaluated futures market efficiency as a way of mitigating the risk associated with live cattle prices and found that the use of the futures contract decreases the variance of returns in the studied period (2002 to 2013) and the coefficient of variation in relation to strategies that did not use hedge.

\section{METHODOLOGY}

\subsection{Research Classification}

Regarding the type, this research is characterized as descriptive in relation to its objectives, since it seeks to describe the price behavior in the market, but not necessarily to verify the cause-effect relationship (GIL, 2006). Regarding the approach, this research is characterized as quantitative, since numerical data were used in its achievement and in the obtained results. Quantitative analysis is present in the collection and processing of data, estimation of econometric models, and analysis of results using statistical techniques (CRESWELL, 2007). The research may also be qualified as ex-post-facto regarding its procedures, since preexisting secondary data were used (GIL, 2006). In empirical terms, this article seeks to statistically compare the performance of six models for the calculation of the optimal hedge ratio in the Brazilian live cattle futures market: Ordinary least squares, BEKK, DCC by Tse and Tsui (2002), DCC by Engle and Sheppard (2001), time-varying beta correlations, and unconditional beta.

\subsection{Analyzed Data}

To calculate the optimal hedge ratio, daily and monthly closing prices were used, comprising the period from $10 / 2 / 2000$ to $8 / 19 / 2014$. The spot market price series was obtained from the Esalq/BM\&F index and the price series of BM\&F live cattle futures market was obtained from Bloomberg. Both quotes are in $\mathrm{R} \$$ by arroba.

Organizações Rurais \& Agroindustriais, Lavras, v. 19, n. 3, p. 160-176, 2017 
The models were estimated using the daily and monthly log-returns $\left(\ln \left(p_{t} / p_{t-1}\right)\right)$ of price series and the estimates performed in OxMetrics software.

Figure 1 shows the series in level with daily frequency, spot and futures, for the analyzed period.

As shown in Figure 1, both series apparently perform similarly, with few series detachments at certain periods. This shows that the futures contract of live cattle is a good asset to hedge the spot contract. The greater the correlation between both series, the more efficient will be the hedge.

As can be seen in Figure 2, futures log-returns fluctuate more than spot log-returns. This can be explained because contracts expire at the end of each month and begin at the beginning of the following month.

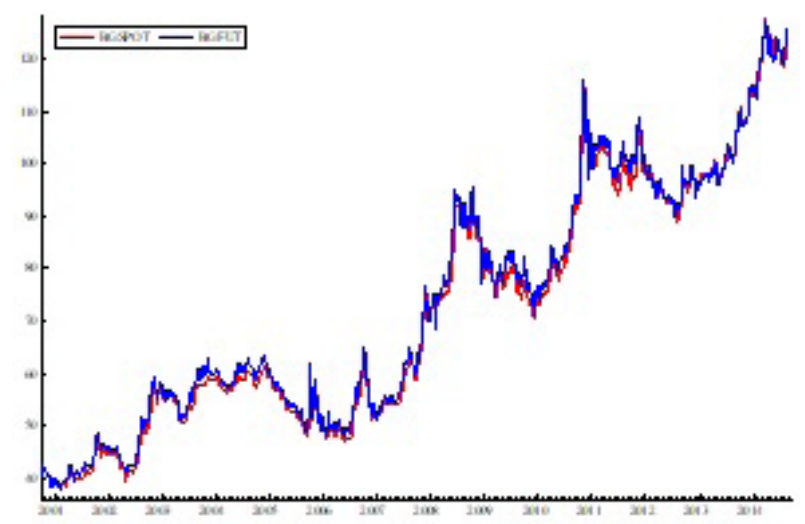

FIGURE 1 - Price for arroba of live cattle spot and futures (daily data)

SOURCE - Elaborated by the authors

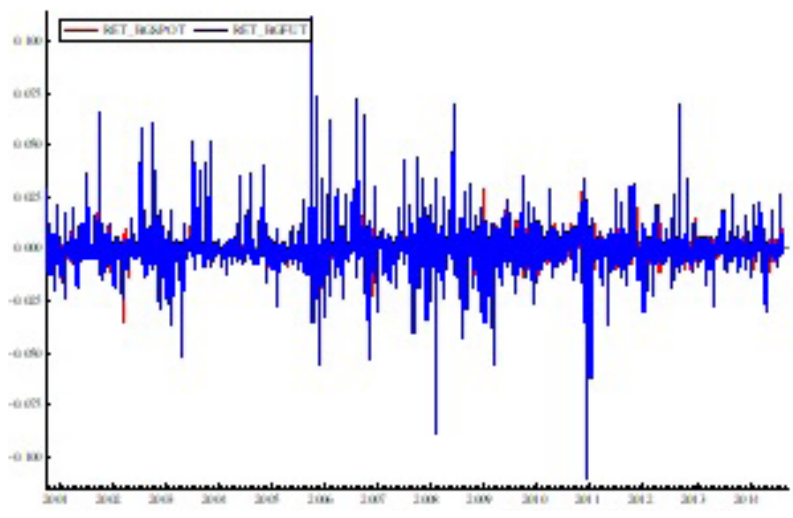

FIGURE 2 - Log-returns for arroba price of live cattle spot and futures (daily data)

SOURCE - Elaborated by the authors

It can be observed in Table 1 that the futures series average is higher than the spot series, as well as the standard deviation (in the futures log-returns, the standard deviation represents twice the spot log-returns). In part, deviations can be explained by contractual change, which leads to more extreme values, hence higher variance. A very high hedge ratio represents a very high risk taken in the futures market. All series, both in level and log-return rejected the null hypothesis of normality in the Jarque-Bera (1980) test and all p-values were zero.

When performing the Augmented Dickey-Fuller (ADF) (DICKEY and FULLER, 1979) unit root test, with no trend and no constant, both for the arroba price series of live cattle spot and futures, the null hypothesis is not rejected that the series have a unit root ( $\mathrm{p}$-values of 1,6640 and 1,9143 , respectively). The null hypothesis is rejected

TABLE 1 - Descriptive statistics (daily series)

\begin{tabular}{lrrrr}
\hline & BGSPOT & \multicolumn{1}{c}{ BGFUT } & \multicolumn{1}{c}{ RET_BGSPOT } & RET_BGFUT \\
\hline Average & 71.87 & 73.03 & 0.0003258 & 0.0003325 \\
Median & 62.35 & 63.99 & 0.0002127 & 0.000165 \\
Maximum & 127.77 & 127.20 & 0.028547 & 0.11182 \\
Minimum & 37.7 & 37.5 & -0.035718 & -0.11023 \\
Standard deviation & 23.41 & 23.26 & 0.0046613 & 0.0091255 \\
Asymmetry & 0.4125 & 0.3710 & -0.100114 & 0.61706 \\
Kurtosis & -1.0346 & -1.0774 & 5.6414 & 27.4577 \\
Jarque-Bera (p-value) & 0.0000 & 0.0000 & 0.0000 & 0.0000 \\
Comments & 3,412 & 3,412 & 3,411 & 3,411 \\
\hline
\end{tabular}

SOURCE - Elaborated by the authors 
to perform the test for the log-returns series $(p-$ valor $=$ 0,000 ). This means that the level series have unit root and the change of scale to log-return make them stationary.

The ARCH-LM test or the autoregressive conditional heteroskedasticity (ENGLE, 1982) in the series is also performed. The null hypothesis was rejected for both the spot price and live cattle futures price series $X^{2}(12)$ $=3399.086$ and $p$-valor $=0,0000$ for spot and $X^{2}(12)=$ 3396364 and $p-$ valor $=0,000$ for futures prices, as well as for the log-return series $X^{2}(12)=464,6553$ and $p$-valor $=0,000$ for spot log-returns and $X^{2}(12)=22.1566$ and $p-$ valor $=0,0358$ for futures log-returns, rejecting $H_{0}$ the $5 \%$ of significance. The result suggests the presence of heteroskedasticity in the residues of all four series.

Figures 3 and 4 present the series at monthly level, spot and futures, and log-returns for the analyzed period.

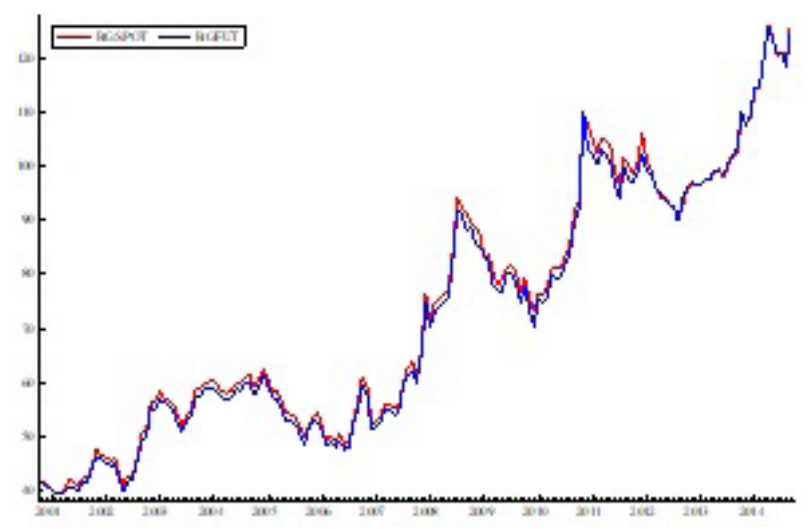

FIGURE 3 - Price for arroba of live cattle spot and futures (monthly data) SOURCE - Elaborated by the authors

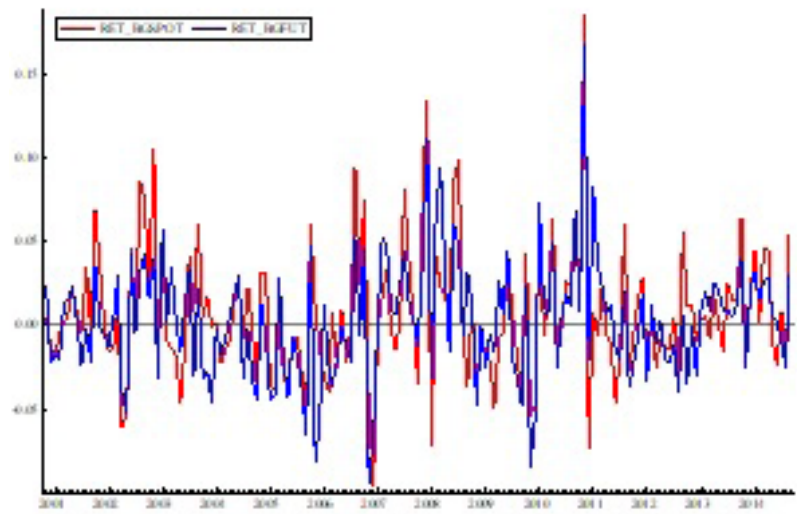

FIGURE 4 - Log-returns for arroba price of live cattle spot and futures (monthly data)

SOURCE - Elaborated by the authors

Observing Figure 3, it can be noted the existence of intervals in the log-return series that occur by the break of expected periodicities. To calculate the log-returns, it was used the log of the difference between the observation of the last business day of the month (that represents the closing) by the first working day of the same month. In addition, the values of the last prices of each month for the series in level were used. It can be noted in Figure 4 that log-returns no longer have such extreme peak values as in the daily data series.

It can be observed in Table 2 that the futures series average becomes lower than the spot series average, as well as the standard deviation that show a value similar to the spot series. The four series keep rejecting normality in the Jarque-Bera test, with p-value equal to zero.

TABLE 2 - Descriptive statistics (monthly series)

\begin{tabular}{ccccc}
\hline & BGSPOT & BGFUT & RET_BGSPOT & RET_BGFUT \\
\hline Average & 73.44 & 72.34 & 0.006589 & 0.00269 \\
Median & 64.98 & 63.62 & 0.00053 & 0.003513 \\
Maximum & 126.52 & 125.89 & 0.185475 & 0.167924 \\
Minimum & 39.1 & 39.21 & -0.096232 & -0.09451 \\
Standard deviation & 23.59 & 23.65 & 0.039734 & 0.036302 \\
Asymmetry & 0.38285 & 0.420074 & 0.957898 & 0.599519 \\
Kurtosis & -1.0855 & -1.0466 & 2.3058 & 2.2267 \\
Jarque-Bera (p-value $)$ & 0.0026 & 0.0022 & 0.0000 & 0.0000 \\
Comments & 166 & 166 & 166 & 166 \\
\hline
\end{tabular}

SOURCE - Elaborated by the authors 
When performing the ADF unit root test both for the arroba price series of live cattle spot and futures, the null hypothesis is not rejected that the series have a unit root (p-values of 0.0872 and 0.1522 , respectively). The null hypothesis is rejected to perform the test for the log-returns series ( $\mathrm{p}$-value $=0.000$ ). This means that the level series are non-stationary, but they become stationary when removed the log-return from them.

\subsection{Models Used to Estimate the Optimal Hedge Ratio}

In this section, the standard and regular form for the calculation of the optimal hedge ratio is defined initially. Afterwards, traditional econometric approaches used to estimate the optimal hedge ratio are detailed: GARCH (ENGLE, 1982; BOLLERSLEV, 1986), BEKK (ENGLE and KRONER, 1995), DCC of Tsé and Tsui (2002), DCC of Engle and Sheppard (2001). Furthermore, as an original contribution of this article, two alternative proposals are detailed, which are used to estimate the optimal hedge ratio: Time-varying beta correlations (TSAY, 2013) and the unconditional beta (MERGNER, 2009).

According to Ederington (1979), the optimal hedge ratio should be those that maximizes the hedger's utility, resulting in minimized risk and maximized portfolio returns. Thus, for the live cattle market, the optimal ratio is those that minimizes the variance of the hedge portfolio:

$$
Y_{t}=\Delta B S_{t}-g \Delta B F_{t}
$$

where:

$Y_{t}$ is the financial result (in ) per arroba;

$\triangle B S_{t}$ is the price variation of live cattle in the spot market; $\triangle B F_{t}$ is the price variation of live cattle in the futures market;

$g$ is a scalar.

As a result of the non-stationary price series, the hedge ratio is estimated through the log-return variations in the spot and futures markets.

The objective of the hedge is to minimize the variance of the financial result per arroba, as follows:

$$
\operatorname{VAR}(Y)=\sigma_{s}^{2}+g^{2} \sigma_{f}^{2}-2 g \sigma_{s f}
$$

where:

$\sigma_{S}^{2}$ is the log-return variance in the spot market;

$\sigma_{f}^{2}$ is the log-return variance in the futures market;

$\sigma_{s f}$ is the covariance between log-returns of the spot and futures markets.
By minimizing the variance in relation to, it has:

$$
\begin{aligned}
& \frac{\Delta V A R(Y)}{\Delta g}=-2 \sigma_{s f}+2 \sigma_{f}^{2} g=0 \\
& g^{*}=\frac{\sigma_{s f}}{\sigma_{f}^{2}}
\end{aligned}
$$

It can be seen that the optimal hedge ratio is given by the covariance ratio of log-returns in the spot and futures markets by the futures return variance.

It is possible to estimate this ratio exactly as the beta OLS estimator of a simple linear regression model. However, the optimal hedge ratio is time-constrained, whereas the linear coefficient of simple linear regression is not constrained to time. Therefore, time-constrained models are expected to yield better results.

\section{GARCH Model}

GARCH model was proposed by Bollerslev (1986). The variance is added and sent to the ARCH model, so that the model becomes more parsimonious and does not have the same estimation problems as the ARCH of Engle (1982).

A GARCH model $(p, q)$ can be presented as follows:

$y_{t}=h_{t} \epsilon_{t}$

$h_{t}=\omega+\sum_{i=1}^{q} \alpha_{i} y_{t-i}^{2}+\sum_{j=1}^{p} \beta_{j} h_{t-j}$

Alternatively, the model can be written as:

$h_{t}=\omega+\alpha(L) y_{t}^{2}+\beta(L) h_{t}$

with

$\alpha(L)=\alpha_{1} L+\ldots \alpha_{q} L^{q}$

$\beta(L)=\beta_{1} L+\ldots \beta_{p} L^{p}$

where,

$y_{t}$ is the innovation in a process for the conditional average of log-returns;

$\epsilon_{t} \sim$ iid $D(0,1)$ is a strong white noise;

$h_{t}$ is the variance of $y_{t}$, time-constrained;

$\omega$ is a constant and $\alpha(\mathrm{L})$ and $\beta(\mathrm{L})$ are obsolete polynomials of order $\pi$ and $\theta$, respectively, which define the structured conditional variance.

GARCH is second order stationary, if is outside the unit circle. The order selection occurs according to 
Akaine information criteria (AIC) of Akaike (1974) and Bayesian information criteria (BIC), which are represented respectively by:

$$
\begin{gathered}
A I C=-L(p) T^{-1}+2 p T^{-1} \\
\text { and } \\
B I C=-L(p) T^{-1}+p T^{-1} \log T
\end{gathered}
$$

where:

$T$ is the number of observations available in the series; $p$ is the number of parameters to be estimated;

$L(p)$ is the log-likelihood (increasing function of ).

The lower the criterion, the better the model, because these criteria are transformations that impose a signal penalty contrary to log-likelihood by the number of estimated parameters. Two other alternative criteria could be used: Hannan-Quinn Information Criterion (HQC), proposed by Hannan and Quinn (1979) and the Shibata Information Criterion (SIC), whose equations are:

$$
\begin{aligned}
& H C Q=L(p) T^{-1}+2 p T^{-1} \log \log T \\
& S I C=-L(p) T^{-1}+\log (T+2 p)-\log T
\end{aligned}
$$

In terms of estimation, in most practical cases, GARCH model $(1,1)$ meets the modeling needs, i.e.:

$$
\begin{aligned}
y_{t} & =h_{t}^{\frac{1}{2}} \epsilon_{t} \\
\mathrm{~h}_{\mathrm{t}} & =\omega+\alpha \mathrm{y}_{(\mathrm{t}-1)}^{2}+\beta \mathrm{h}_{(\mathrm{t}-1)},
\end{aligned}
$$

Where, $\omega>0, \alpha>0, \beta>0$ ensuring that $h_{t} \geq 0$. By making recursive substitutions of the term $h_{t-1}$, it is shown the equivalence to an $\mathrm{ARCH}(\infty)$ model. If $\alpha+\beta$ $<1$, GARCH process $(1,1)$ can be written as an ARMA $(1,1)$, which will be second order stationary.

An important GARCH characteristic is the excess of kurtosis, even when the distribution of is normal. The kurtosis is given by:

$$
K_{y}=\frac{3 E\left[h_{t}\right]^{4}}{\left(E\left[h_{t}\right]^{2}\right)^{2}}=\frac{\left(3\left[1-(\alpha+\beta)^{2}\right]\right)}{\left(1-(\alpha+\beta)^{2}-2 \alpha^{2}\right)} .
$$

Which is supposed to be higher than 3 , since $E[h]^{4}$ $>\left(E[h]_{t}^{2}\right)^{2}$, by the inequality of Jensen, i.e., $1-(\alpha+\beta)^{2}>$ $1-(\alpha+\beta)^{2}-2 \alpha^{2}$.

All of GARCH family models are able to deal with volatility clusters. This can be observed by the dynamics of equation (1). A high value of $y_{t-1}^{2}$ leads to a high value of $h_{t}$, a high value of $y_{t}^{2}$ leads to a high value of $h_{\mathrm{t}+1}$, and so on. Generally, the sum of $\alpha(\mathrm{L})$ and $\beta(\mathrm{L})$ is close to one, which causes persistence of volatility.

Tests can be performed for linear and non-linear GARCH. In order to detect conditional heteroskedasticity, or ARCH effect in the residues, the ARCH-LM test, proposed by Engle (1982) is performed. The null hypothesis of the test is, in the case of an $\operatorname{ARCH}(q)$ :

$$
H_{0}: \alpha_{1}=\alpha_{2}=\ldots=\alpha_{q}=0
$$

Presence of the ARCH effect.

The test follows a distribution, being the significance level.

\section{BEKK Model}

The BEKK model of Engle and Kroner (1995) can be represented as follows:

$$
\sum_{t}=A_{0} A^{\prime}{ }_{0}+\sum_{i=1}^{m} A_{i}\left(u_{t-i} u_{t-i}^{\prime}\right) A_{i}^{\prime}+\sum_{j=1}^{n} B_{j} \sum_{t-j} B^{\prime}{ }_{j}
$$

where,

$A_{0}$ is a lower triangular matrix;

$A_{i}$ and are unrestricted square matrices. for and for .

$u_{t}$ is the residue

Thus, the expression represents the model variance. Due to the limited number of observations, both and are equal to $1, \Sigma_{\mathrm{t}}$ is positive definite, since $A_{0} A_{0}^{\prime}$ is positive definite. The model allows dynamic dependence between the volatility series.

However, the model has disadvantages, since many of the estimated parameters are statistically insignificant, causing complications in modeling.

\section{Model - Dynamic Conditional Correlation}

The dynamic conditional correlation model has the following structure:

$\sum_{t}=\Delta_{t} R_{t} \Delta_{t}$

where,

$\Delta_{t}$ is a diagonal matrix with univariate GARCH;

$\mathrm{R}_{\mathrm{t}} \mathrm{is}$ a correlation matrix of the standardized residues.

The dynamic correlation models of Tse and Tsui (2002) differ from the DCC of Engle and Sheppard (2001) in the correlation matrix of the standardized residues.

In the case of DCC-TT, the matrix dynamics is represented by: 
$R_{t}=\left(1-\gamma_{1}-\gamma_{2}\right) R+\gamma_{1} \varphi_{t-1}+\gamma_{2} R_{t-1}$,

with,

$\varphi_{i, j t-1}=\frac{\sum_{m=1}^{M} u_{i t-m} u_{j t-m}}{\sqrt[2]{\sum_{m=1}^{M} u_{i t-m}^{2} \sum_{m=1}^{M} u_{i t-m}^{2}}}$

where,

$\gamma_{1}$ and $\gamma_{2}$ are non-negative parameters with sum lower than; $R$ is an matrix $N \times N$ positive definite;

$\varphi_{\mathrm{t}-1}$ is the correlation matrix $N \times N$.

The dynamics of the correlation matrix of the standardized residues for the DCC of Engle and Sheppard is given by:

$$
R_{t}=\operatorname{diag}\left(Q_{t}\right)^{\frac{1}{2}} Q_{t} \operatorname{diag}\left(Q_{t}\right)^{\frac{1}{2}}
$$

with,

$$
\mathrm{Q}_{\mathrm{t}}=(1-\alpha-\beta) \overline{\mathrm{Q}}+\alpha \mathrm{u}_{\mathrm{t}-1} \mathrm{u}_{\mathrm{t}-1}^{\prime}+\beta \mathrm{Q}_{\mathrm{t}-1}
$$

where,

$\mathrm{Q}_{\mathrm{t}}$ is a positive definite $\mathrm{N} \times \mathrm{N}$ matrix;

$\bar{Q}$ is the unconditional variance matrix of (residue);

$\alpha$ and $\beta$ are positive parameters whose sum is lower than .

\section{Models with Time-varying Correlations and Betas}

According to Tsay (2013), another applied strategy can be the use of GARCH to obtain the time-varying correlation between the log-returns of spot and future series. In this research, univariate GARCH models were used to study these correlations, in which it is assumed that:

$$
\begin{aligned}
& \sigma_{s+f}^{2}=\sigma_{s}^{2}+\sigma_{f}^{2}+2 \sigma_{s f} \\
& \text { and } \\
& \sigma_{s-f}^{2}=\sigma_{s}^{2}+\sigma_{f}^{2}-2 \sigma_{s f}
\end{aligned}
$$

In other words, the futures series variance plus the spot series is given by the sum of spot series variances and the futures series plus twice the covariance between the series. The of the spot series variance minus the futures series is given by the sum of spot series variances and the future series minus twice the covariance between the series. Subtracting the equation (25) from equation (24), it has:

$$
\sigma_{s+f}^{2}-\sigma_{s-f}^{2}=4 \sigma_{s f}
$$

that is,

$$
\sigma_{s f}=\frac{1}{4}\left(\sigma_{s+f}^{2}-\sigma_{s-f}^{2}\right)
$$

By this means, it is possible to obtain the conditional covariance of the series, i.e., it is given by the difference of the variance of the sum of live cattle spot and futures series and the variance of the difference of the live cattle spot and futures series. This result is used to find the optimal hedge ratio represented by equation (4):

$$
g^{*}=\frac{\sigma_{s f}}{\sigma_{f}^{2}}
$$

The conditional variance of futures series is found through a GARCH.

\section{Unconditional Beta Model}

According to Mergner (2009), it is possible to obtain an unconditional beta from equation (4):

$$
\begin{gathered}
g^{*}=\frac{\sigma_{s f}}{\sigma_{f}^{2}} \\
\text { where, } \\
\sigma_{s f}^{2}=\rho_{s f} \cdot \sigma_{s} \cdot \sigma_{f}
\end{gathered}
$$

where $\rho_{\text {sf }}$ represents the correlation coefficient between the spot and futures returns series and may be the Pearson, Spearman, or Kendall coefficient. As a natural consequence:

$$
\sigma_{s f}^{2}=\rho_{s f} \cdot \sqrt{\sigma_{s}^{2}} \cdot \sqrt{\sigma_{f}^{2}}
$$

It is possible to obtain and through univariate GARCH models, thus reaching at the unconditional beta described in equation 30 :

$$
g^{*}=\rho_{s f} \cdot \frac{\sqrt{\sigma_{s}^{2}}}{\sqrt{\sigma_{f}^{2}}}
$$

\section{RESULTS}

\subsection{Estimation of the Hedge Ratio by Ordinary Least Squares:}

Estimates of the log-returns of live cattle prices in the spot market versus log-returns of prices in the futures 
market for daily and monthly data are summarized in equations 31 and 32, respectively.

$$
\begin{aligned}
& \text { ret_bgspot }=0,0002748+0,1533745 r_{-} t_{-} b g f u t \\
& (0.000762)(0.0083448) \\
& {[0.000315][0.0000]}
\end{aligned}
$$

The p-values of the estimates are represented in brackets and deviations in parentheses. Estimating by OLS, it is obtained an optimal hedge ratio of $15.34 \%$, a low value comparing with the market rates.

$$
\begin{aligned}
& \text { ret_bgspot }=0,004310+0,847186 r_{\text {ret_bgfut }} \\
& \begin{array}{ll}
(0.001964) & (0.054117) \\
{[0.0296]} & {[0.0000]}
\end{array}
\end{aligned}
$$

The p-values of the estimates are represented in brackets and deviations in parentheses. Estimating by OLS, the optimal hedge ratio is $84.71 \%$.

\subsection{Hedge ratio Estimation by the BEKK Model:}

For the multivariate GARCH BEKK, the BEKKdiagonal model of the OxMetrics software is estimated to obtain the variance and covariance matrix. This model enables the matrix to be positive definite and allows a dynamic dependence of the model. Figures 5 and 6 represent the optimal hedge ratio for daily and monthly data, respectively, calculated using the BEKK model. It is worth mentioning that the multivariate GARCH models are estimated with constants in the average and variance equations.

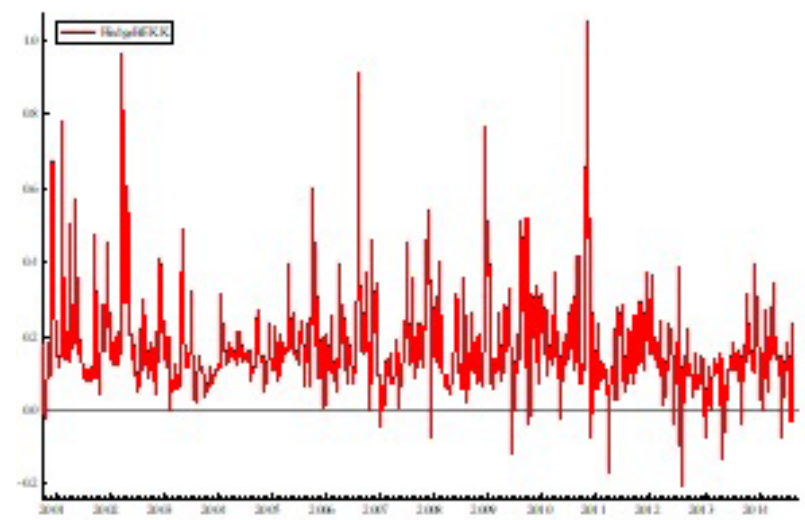

FIGURE 5 - Hedge ratio estimated by the BEKK model (daily data)

SOURCE - Elaborated by the authors

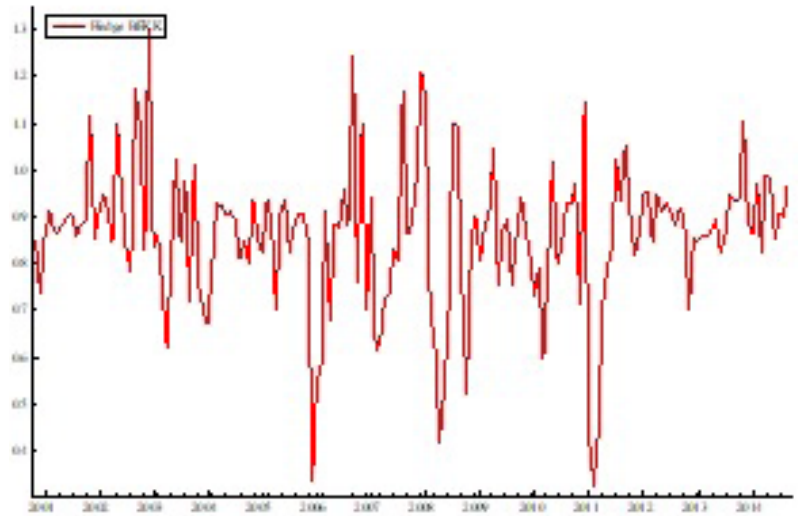

FIGURE 6 - Hedge ratio estimated by the BEKK model (monthly data)

SOURCE - Elaborated by the authors

In relation to daily data, some variations in the ratios can be noted through Figure 5. The maximum value is 1.053694 and minimum is -0.205909 . Both valuesare against hedge theory and the transaction does not pay off in this case. If the ratio is negative, the hedger buys futures (if he is bought in spot) or sells futures (if he is sold in spot). When the ratio is greater than 1 , it means that hedger is leveraged in spot or futures. The average ratio is 0.163663 , a value lower than that practiced by the market.

Regarding the monthly data, as shown in Figure 6 , the maximum value is 1.3019 and minimum is 0.3262 . The maximum was against the hedge theory, because the ratio is higher than 1 , meaning that hedger is leveraged in spot or futures. The average ratio is 0.85892 .

\subsection{Estimation of the Hedge Ratio by the DCC-TT Model:}

When estimating the hedge ratio by DCC of TseTsui (2002) for daily data, the model average drops in relation to the other models $(0.1181)$. The BEKK model presents more extreme values than the DCC-TT, since the maximum in this model is 0.701231 and the minimum is 0.028292 , as shown in Figure 7.

When estimating the hedge ratio by the DCC of Tse-Tsui with monthly data, the model average increases in relation to the other models $(0.89201)$. As shown in Figure 8, the BEKK model showed more extreme values than the DCC-TT, since the maximum in this model is 1.2083 and the minimum is 0.44127 .

Organizações Rurais \& Agroindustriais, Lavras, v. 19, n. 3, p. 160-176, 2017 


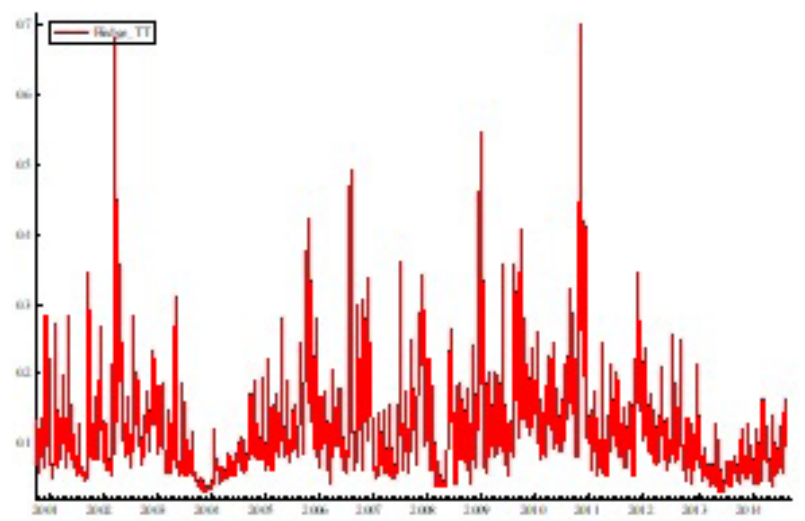

FIGURE 7 - Hedge ratio estimated by DCC-TT model (daily data)

SOURCE - Elaborated by the authors

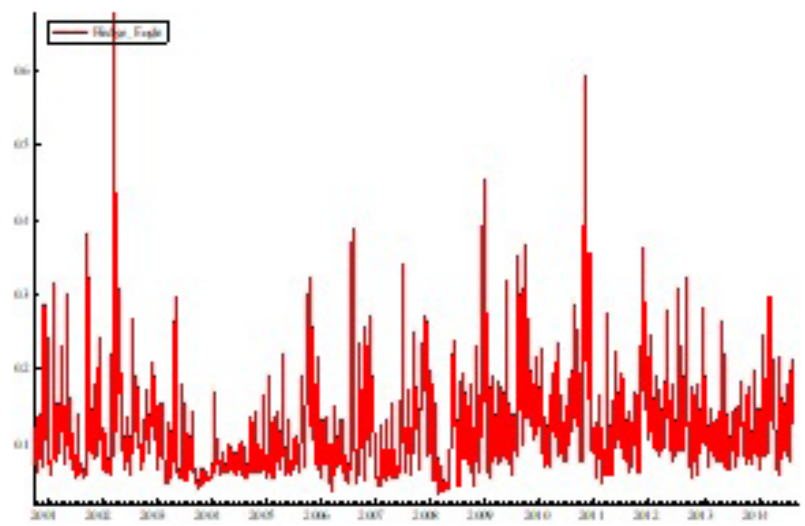

FIGURE 8 - Hedge ratio estimated by DCC-TT model (monthly data)

SOURCE - Elaborated by the authors

\subsection{Estimation of Hedge Ratio by DCC Model of Engle and Sheppard (ES):}

As shown in Figure 9, the DCC model of Engle and Sheppard (2001) shows lower volatility than the DCC-TT. It also has a lower average $(0.116734)$ and lower extreme values(maximum of 0.677887 and minimum of 0.034519 ).

Estimating the DCC-ES model with monthly data (Figure 10), it is observed that it shows lower volatility than the DCC-TT. It also has a higher average (0.89225) and lower extreme values(maximum of 1.1962 and minimum of 0.43389 ).

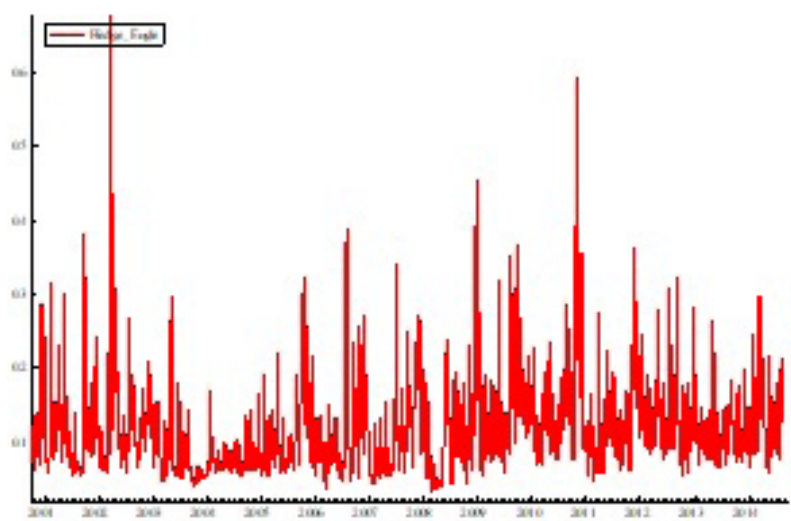

FIGURE 9 - Hedge ratio estimated by DCC-ES model (daily data)

SOURCE - Elaborated by the authors

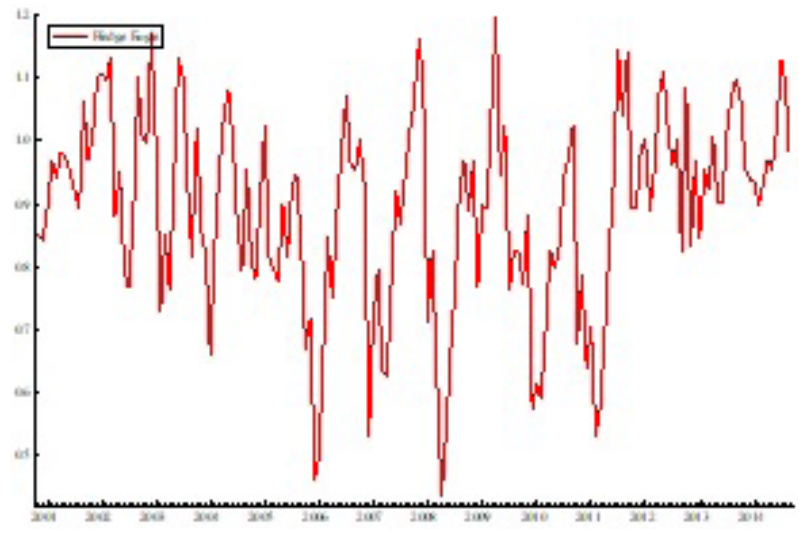

FIGURE 10 - Hedge ratio estimated by DCC-ES model (monthly data)

SOURCE - Elaborated by the authors

\subsection{Estimation of the Hedge Ratio by Time-varying Beta Correlations:}

By obtaining the conditional covariance of the series given by the difference of the variance of the sum of live cattle spot and futures series and the variance of the difference of live cattle spot and futures series, it is possible to obtain the optimal hedge ratio for each period. The maximum value is 0.403983 while the minimum is -0.1016 , with lower volatility than DCC models. However, the average hedge ratio estimated by this model was very low, only 0.018594 , according to Figure 11. 


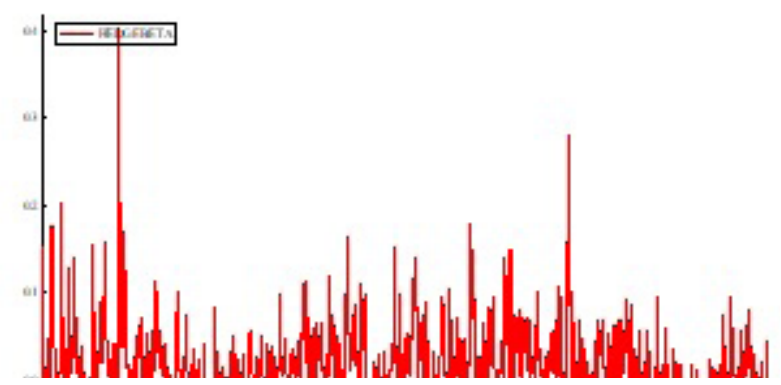

FIGURE 11 - Hedge ratio estimated by time-varying beta correlation (daily data)

SOURCE - Elaborated by the authors

Figure 12 shows the optimal hedge ratio obtained by this model, the maximum value is 1.5382 while the minimum is 0.34456 , with higher volatility than the DCC models. However, the average hedge ratio estimated by this model was lower $(0.87513)$.

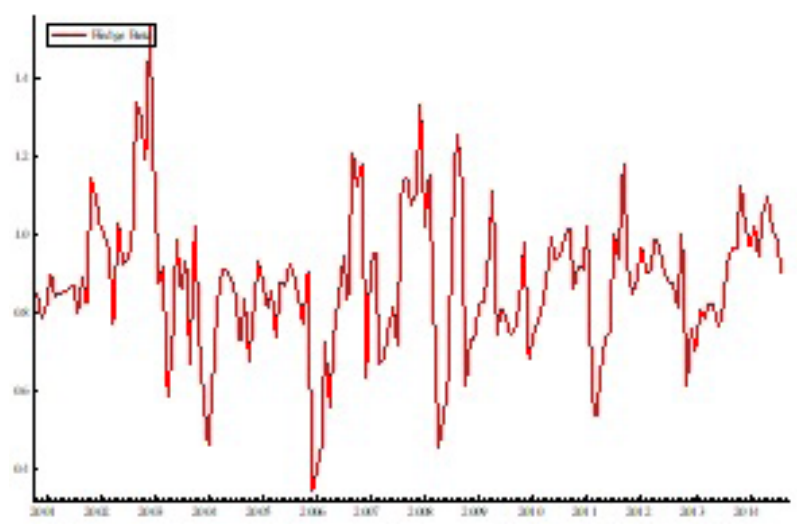

FIGURE 12 - Hedge ratio estimated by time-varying beta correlation (monthly data)

SOURCE - Elaborated by the authors

\subsection{Estimation of the Hedge Ratio for the Unconditional Beta (CAPM):}

When estimating the conditional variance for live cattle spot and futures series, considering monthly data, it is possible to obtain the optimal hedge ratio by multiplying the ratio of standard deviation of the spot and future log-returns by the correlation coefficient (Spearman). The maximum value is 1.2498 while the minimum is 0.44567 , also showing lower volatility than the DCC and BEKK models, besides lower average (0.88085), which was only lower than the OLS ratio.

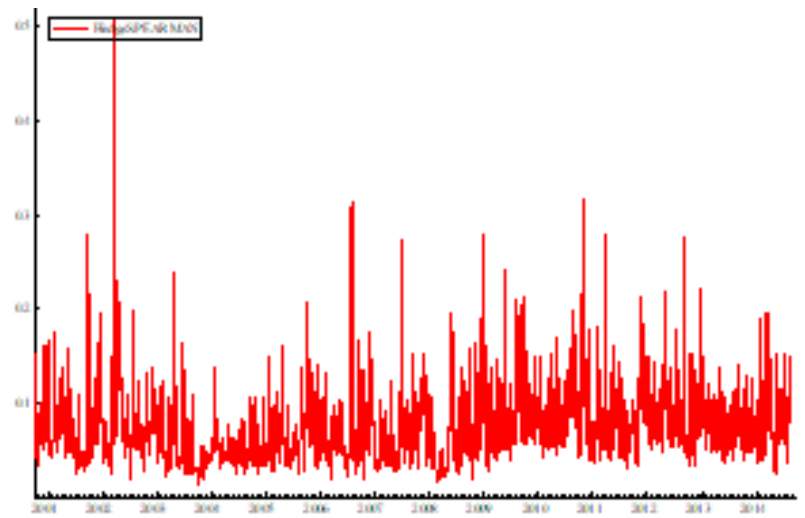

FIGURE 13 - Hedge ratio estimated by unconditional betas (daily data)

SOURCE - Elaborated by the authors

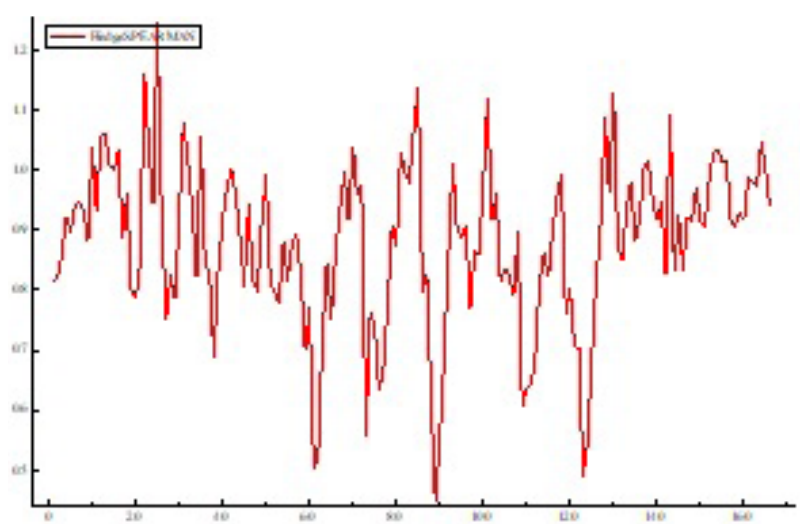

FIGURE 14 - Hedge ratio estimated by unconditional betas (monthly data)

SOURCE - Elaborated by the authors

\subsection{Efficiency of Models:}

One way to analyze the efficiency of optimal hedge ratio models can be to estimate the variance of hedge portfolio variance. Returning to equation 1 of the hedge portfolio:

$$
Y_{t}=\Delta B S_{t}-g \Delta B F_{t}
$$

The variance reduction is calculated in relation to the non-hedged portfolio $(g=0)$, i.e., the variance of the spot log-returns. Moreover, the Sharpe ratio is calculated by dividing the portfolio's average return by its variance. The used risk-free rate $\left(\mathrm{R}_{f}\right)$ was the CDI.

As shown in Table 3, the hedge ratio that most reduced the variance was that calculated by the BEKK, followed by the CAPM unconditional beta, DCC-Engle, 
TABLE 3 - Efficiency of models

\begin{tabular}{lrrr}
\hline Strategy & Variance & Reduction of variance (\%) & Sharpe ratio \\
\hline Unhedged & 0.001579 & 0.0000 & 4.1729 \\
OLS & 0.000633 & 0.5991 & 6.8086 \\
BEKK & 0.000587 & 0.6283 & 8.7166 \\
DCC-TT & 0.000619 & 0.6080 & 6.8625 \\
DCC-ES & 0.000618 & 0.6088 & 6.9222 \\
Time-varying beta correlation & 0.000664 & 0.5796 & 5.0403 \\
Unconditional beta CAPM & 0.000612 & 0.6126 & 7.3220 \\
\hline
\end{tabular}

SOURCE - Elaborated by the authors

DCC-TT, and beta of varying correlations. This same order represents the models that maximized the Sharpe ratio. These results are different from those found by Lazzarini (2010) where DCC (TT and Engle) models were better at the criterion of variance reduction and Sharpe ratio maximization.

It should be noted that the unhedged strategy is the worst result, since it is a consequence of the return and risk without hedging. The second worst strategy is OLS, which is also an expected result, since all other methodologies are more accurate to capture the variability relationship between the spot and futures series.

\section{CONCLUSION}

The aim of this article was to identify the best model to obtain the hedge ratio in the Brazilian live cattle market, by comparing six models: OLS, DCC of Engle and Sheppard, DCC of Tsé and Tsui, BEKK, time-varying beta correlation, and unconditional beta.

Lazzarini (2010) justifies the low values of hedge ratios for daily data, suggesting that the drop in the temporal expectation with the change of contracts increases greatly the variance of futures series, reducing the hedge ratio. One solution would be to use monthly series, being the trading prices as observations of some day of the month (days 1,15 , or 30 ).

From this suggestion, daily and monthly data were used in this article, besides values of the last prices of each month for the series in level. Thereby, it is possible to obtain higher hedge ratios when estimating monthly data. Additionally, hedge ratios were estimated using more methodological alternatives. The models that were most successful in reducing variance and maximizing the Sharpe ratio were BEKK, followed by the unconditional beta.
In all models, for both studies, the estimated hedge ratios for daily data were also low. This leads to believe that such justification is contained in the data itself and not in the used models.

Finally, it is worth emphasizing that this study contributed to empirically evidence that there is a differentiated effect in the model choice to determine the optimal hedge ratio in futures contracts, with a direct impact on the risk management and the return of agents involved in the live cattle market.

\section{REFERENCES}

AKAIKE, H. A new look at the statistical model identification. IEEE Transactions on Automatic Control, New York, v. 19, n. 6, p. 716-723, 1974.

ALIZADEH, A.; NOMIKOS, N. A Markov regime: switching approach for hedge stock index. The Journal of Future Markets, New York, v. 24, n. 4, p. 649-674, 2004.

AMORIM NETO, C. S. Efetividade do hedge para o boi gordo com contratos futuros da BM\&FBovespa: análise para os estados de São Paulo e Goiás. 2015. 49 f. Dissertação (Mestrado em Economia Aplicada)-Escola Superior de Agricultura "Luiz de Queiroz", Universidade de São Paulo, Piracicaba, 2015.

ANDERSON, R. W.; DANTHINE, J. Cross hedging. Journal of Political Economy, Chicago, v. 89, n. 6, p. 1182-1196, 1981.

BERA, A. K.; GARCIA, P.; ROH, J. Estimation of timevarying hedge ratios for corn and soybeans: $B G A R C H$ and random coefficient approaches. 1998. Disponível 
em: $<$ http://ssrn.com/abstract $=61191>$. Acesso em: 10 mar. 2016.

BHADURI, S. N.; DURAI, S. R. S. Optimal hedge ratio and hedging effectiveness of stock index futures: evidence from India. Journal of Macroeconomics and Finance in Emerging Market Economies, London, v. 1, n. 1, p. 121-134, 2008.

BITENCOURT, W.; SILVA, W. S.; SÁFADI, T. Hedge dinâmico: uma evidência para os contratos futuros brasileiros. Organizações Rurais \& Agroindustriais, Lavras, v. 8, n. 1, p. 71-78, jan./abr. 2006.

BOLLERSLEV, T. Generalized autoregressive conditional heteroscedasticity. Journal of Econometrics, Amsterdam, v. 31, n. 3, p. 307-327, 1986.

BOLSA DE MERCADORIAS \& FUTUROS. Disponível em: $<\mathrm{http}: / / \mathrm{www} \cdot$ bmfbovespa.com.br/>. Acesso em: 10 maio 2014.

BRASIL. Ministério da Agricultura, Pecuária e Abastecimento. Estatísticas de comercio exterior. Disponível em: <http://www.agricultura.gov.br/ internacional/indicadores-e-estatisti-cas $>$. Acesso em: 10 maio 2014.

BROWN, S. L. A reformulation of the portfolio model of hedging. American Journal of Agricultural Economics, Saint Paul, v. 67, n. 3, p. 508-512, 1985.

CENTRO DE ESTUDOS AVANÇADOS EM ECONOMIA APLICADA. Indicadores de preços. Disponível em: $<$ http://cepea.esalq.usp.br/boi/>. Acesso em: 10 ago. 2014.

CHIODI, L. et al. Análise da efetividade de hedging com os contratos futuros de soja na BM\&F e CBOT. In: CONGRESSO DA SOCIEDADE BRASILEIRA DE ECONOMIA, ADMINISTRAÇÃO E SOCIOLOGIA RURAL, 43., 2005, Ribeirão Preto. Anais... Brasília, DF: SOBER, 2005. 1 CD-ROM.

COSTA, C. C. da; GUILhOTO, J. J. M.; IMORI, D. Importância dos setores agroindustriais na geração de renda e emprego para a economia brasileira. Revista de Economia e Sociologia Rural, Rio de Janeiro, v. 51, n. 4, p. 797-814, out./dez. 2013.
CRESWELL, J. W. Projeto de pesquisa: métodos qualitativo, quantitativo e misto. 2. ed. Porto Alegre: Artmed, 2007.

CRUZ, A.; LIMA, J. Efetividade nas operações de hedge com contratos de boi gordo BM\&FBovespa. Revista de Economia e Administração, São Paulo, v. 8, n. 1, p. 120140, jan./mar. 2009.

DICKEY, D. A.; FULLER, W. A. Distribution of estimators statistics for autoregressive time series with a unit root. Journal of the American Statistical Association, New York, v. 74, n. 366, p. 427-431, 1979.

DUARTE JÚNIOR, A. M. Risco: definições, tipos, medição e recomendações para seu gerenciamento. Resenha BM\&F, São Paulo, v. 114, p. 25-33, 1996.

EDERINGTON, L. The hedging performance of the new futures markets. The Journal of Finance, New York, v. 34, n. 1, p. 157-170, 1979.

ENGLE, R. F. Autoregressive conditional heteroscedasticity with estimates of the variance of United Kingdom inflation. Econometrica, Chicago, v. 50, n. 4, p. 987-1007, 1982.

ENGLE, R. F.; GRANGER, C. W. J. Cointegration and error correction: representation, estimation and testing. Econometrica, Chicago, v. 55, n. 2, p. 251-276, 1987.

ENGLE, R. F.; KRONER, K. F. Multivariate simultaneous GARCH. Econometric Theory, Cambridge, v. 11, n. 2, p. 122-150, 1995.

ENGLE, R. F.; SHEPPARD, K. Theoretical and empirical properties of dynamic conditional correlation multivariate GARCH. Cambridge: NBER, 2001. 46 p. (NBER Working Paper, 8554).

GIL, A. C. Métodos e técnicas de pesquisa social. 5. ed. São Paulo: Atlas, 2006.

GOMES, F. C. Determinação da razão de hedge: um estudo sobre as teorias de hedging. Revista de Administração de Empresas, São Paulo, v. 27, n. 4, p. 38-44, out./dez. 1987.

GRAY, S. F. An analysis of conditional regimeswitching models. Duke: Fuqua School of Business, Duke University, 1995. (Working Paper).

Organizações Rurais \& Agroindustriais, Lavras, v. 19, n. 3, p. 160-176, 2017 
GUIMARÃES, R. L. Razão ótima de hedge em função do horizonte de hedge e da periodicidade dos dados: uma aplicação no mercado de boi gordo brasileiro. 2005. 88 f. Dissertação (Mestrado em Finanças e Economia Empresarial)-Escola de Economia da Fundação Getúlio Vargas, São Paulo, 2005.

HANNAN, E. J.; QUINN, B. G. The determination of the order of an autoregression. Journal of The Royal Statistical Society, London, v. 41, p. 190-195, 1979. Series B.

HARDAKER, J. B. et al. Coping with risk in agriculture. $2^{\text {nd }}$ ed. Cambridge: CABI, 2004.

HICKS, J. R. Value and capital. $2^{\text {nd }}$ ed. London: Oxford University Press, 1939.

HULL, J. Introdução aos mercados futuros e de opções. São Paulo: BM\&F, 2011.

JARQUE, C. M.; BERA, A. K. Efficient tests for normality, homoscedasticity and serial independence of regression residuals. Economics Letters, Amsterdam, v. 6, n. 3, p. 255-259, 1980.

JOHNSON, L. L. The theory of hedging and especulation in commodidy futures. Review of Economic Studies, Stockholm, v. 27, n. 3, p. 139-151, 1960.

JORION, P. Value at risk: the benchmark for managing financial risk. $3^{\text {rd }}$ ed. New York: McGraw-Hill, 2007.

KEYNES, J. M. A treatise on money. New York: H. B. Jovanovich, 1930.

LAZZARINI, D. A taxa ótima de hedge no mercado brasileiro do boi gordo: uma abordagem com BEKK, DCC e BEKK com dummies de safra e entressafra. 2010. 41 f. Dissertação (Mestrado em Econometria Financeira)Escola de Economia da Fundação Getúlio Vargas, São Paulo, 2010.

LEE, H.; YODER, J. A bivariate Markov regime switching approach to estimate time varying minimum variance hedge ratios. Washington: School of Economics Sciences of Washington State University, 2005. (Working Paper, 5).

MARKOWITZ, H. Portfolio selection. The Journal of Finance, New York, v. 7, n. 1, p. 77-91, 1952.
MERGNER, S. Applications of state space models in finance. Göettingen: Universitäts Verlag Göettingen, 2009.

MONTEZANO, R. M. Introdução aos mercados futuros de índices de ações. São Paulo: BM\&F/IBMEC, 1987.

MORGAN, J. P. Riskmetrics: technical document. New York: Morgan Guaranty Trusty Company of New York, 1996.

MYERS, R. J. Estimating-time varying optimal hedge ratios on futures markets. Journal of Futures Markets, New York, v. 11, n. 1, p. 39-53, 1991.

MYERS, R. J.; THOMPSON, S. R. Generalized optimal hedge ratio estimation. American Journal of Agricultural Economics, Saint Paul, v. 71, n. 4, p. 858867, Nov. 1989.

OLIVEIRA NETO, O. J.; FIGUEIREDO, R. S. Análise das operações de hedge do boi gordo no mercado futuro da BM\&F para o estado de Goiás. Revista Gestão e Planejamento, Salvador, v. 9, n. 1, p. 77-93, 2008.

PINDYCK, R. S.; RUBINFELD, D. L. Microeconomia. 6. ed. São Paulo: Prentice Hall, 2006.

ROCHELLE, T. C. P. O contrato futuro de boi gordo: uma análise do impacto da introdução da liquidação financeira sobre o risco de base. 1997. 140 p. Dissertação (Mestrado em Agronomia)-Escola Superior de Agricultura "Luiz de Queiroz", Universidade de São Paulo, Piracicaba, 1997.

RODRIGUES, M. A.; ALVES, A. F. Efetividade e razão ótima de hedge: um survey. In: CONGRESSO DA SOCIEDADE BRASILEIRA DE ECONOMIA, ADMINISTRAÇÃO E SOCIOLOGIA RURAL, 48., 2010, Campo Grande. Anais... Brasília, DF: SOBER, 2005. 1 CD-ROM.

ROLFO, J. Optimal hedging under price and quantity uncertainty: the case of a Cocoa Producer. The Journal of Political Economy, Chicago, v. 88, n. 1, p. 100-116, Feb. 1980.

SHIBATA, R. Selection of the order of an autoregressive model by akaike's information criterion. Biometrika, London, v. 63, n. 1, p. 117-126, 1976. 
SOUZA, R. S.; CUNHA, C. A.; WANDER, A. E. Efetividade e razão ótima de hedge para operações de boi gordo em Goiás. Latin American Journal of Business Management, Taubaté, v. 3, n. 2, p. 41-60, 2012.

STEIN, J. The simultaneous determination of spot and futures prices. American Economic Review, Nashville, v. 1, n. 5, p. 1012-1025, 1961.

TSAY, R. S. An introduction to analysis of financial data with R. New Jersey: Wiley, 2013.

TSE, Y. K.; TSUI, A. K. C. A multivariate generalized autoregressive conditional heteroscedasticity model with timevarying correlations. Journal of Business and Economic Statistics, Washington, v. 20, n. 3, p. 351-362, July 2002.
UNITED STATES DEPARTAMENT OF AGRICULTURE. Foreign Agricultural Service. Production, supply, and distribution (PS\&D). Disponível em: <http://www.fas.usda.gov/psdonline/>. Acesso em: 10 dez. 2014.

WORKING, H. Hedging reconsidered. Journal of Farm Economics, Ithaca, v. 35, n. 4, p. 544-561, 1953.

ZILLI, J. B. et al. Razão ótima de hedge para os contratos futuros do boi gordo: uma análise do mecanismo de correção de erros. In: CONGRESSO DA SOCIEDADE BRASILEIRA DE ECONOMIA, ADMINISTRAÇÃO E SOCIOLOGIA RURAL, 46., 2008, Rio Branco. Anais... Brasília, DF: SOBER, 2005. 1 CD-ROM. 